\title{
Bidirectional (Negative/Positive) Interference of Oleandrin and Oleander Extract on a Relatively New LOCI Digoxin Assay Using Vista 1500 Analyzer
}

\author{
Amitava Dasgupta, ${ }^{1 *}$ Kerry J. Welsh, ${ }^{1}$ Shen-An Hwang, ${ }^{1}$ Myrtle Johnson, ${ }^{2}$ \\ and Jeffrey K. Actor ${ }^{1}$ \\ ${ }^{1}$ Department of Pathology and Laboratory Medicine, The University of Texas Medical School \\ at Houston, Texas \\ ${ }^{2}$ Department of Laboratory Services, Memorial Hermann Hospital, Texas Medical Center, Houston, Texas
} Background: Oleander interferes with
serum digoxin measurements using various
immunoassays. The potential interference
of oleander and its active ingredient, ole-
andrin, with a relatively new homogenous
sequential chemiluminescent digoxin assay
based on luminescent oxygen channeling
technology (LOCl digoxin assay, Siemens
Diagnostics) has not been previously re-
ported. Methods: Aliquots of a digoxin-free
serum pool were supplemented with in-
creasing concentrations of oleandrin, or
with oleander extract, followed by mea-
suring the apparent digoxin concentrations
using the LOCI digoxin assay using Vista
1500 analyzer. Mice were fed oleandrin or
oleander extract, and their blood digoxin
levels at 1 and $2 \mathrm{~h}$ were measured with the
LOCI digoxin assay. In addition, two digoxin
serum pools were prepared by combining
sera of patients receiving digoxin; aliquots

Key words: oleander; digoxin; interference; LOCI digoxin assay of both pools were supplemented with oleandrin or oleander extract and digoxin concentrations were again measured. Attempts to overcome this interference were made by measuring free digoxin concentration using a third digoxin pool. Results: Significant apparent digoxin concentrations were observed after supplementing aliquots of the drug-free serum pool with oleandrin or oleander extract. Mice fed with oleandrin or oleander extract also showed apparent digoxin levels 1 and $2 \mathrm{~h}$ after feeding. Digoxin values were also falsely lower or elevated (bidirectional interference) when aliquots of digoxin serum pools were further supplemented with oleandrin or oleander extract depending on concentration; this interference was not eliminated by free digoxin monitoring. Conclusions: Oleandrin interferes with LOCI digoxin assay. J. Clin. Lab. Anal. 28:16-20, 2014. (c) 2013 Wiley Periodicals, Inc.

\section{INTRODUCTION}

Oleander (Nerium oleander) is an evergreen ornamental shrub that grows in the Southern United States, as well as in other parts of the world. All components of this plant are toxic due to the presence of oleandrin, a cardiac glycoside. Human exposures to oleander include accidental exposure especially by children, taking oleander containing herbal supplements, drinking oleander tea, and criminal poisoning (1-5). Recently, Papi et al. reported the deaths of a man and woman due to oleander poisoning (6).

Due to structural similarity with digoxin, oleandrin interferes with many digoxin immunoassays including FPIA (fluorescence polarization immunoassay), microparticle enzyme immunoassay, SYNCHRON digoxin, EMIT digoxin assay, and Tina-Quant digoxin assay (6-10). The magnitude of interference was highest with the FPIA assay; however, this assay was recently discontinued by Abbott Laboratories (Siemens, Deerfiled, IL). We previously reported the interference of oleander with the digoxin immunoassay (Flex Reagent Cartridge) marketed

\footnotetext{
* Correspondence to: Dr. Amitava Dasgupta, Department of Pathology and Laboratory Medicine, The University of Texas Medical School at Houston, 6431 Fannin, MSB 2.292, Houston, TX 77030. E-mail: Amitava.Dasgupta@uth.tmc.edu
}

Received 23 February 2013; Accepted 15 May 2013

DOI 10.1002/jcla.21637

Published online in Wiley Online Library (wileyonlinelibrary.com). 
by Siemens Diagnostics for application on Dimension analyzers (11), which was recently replaced with a new homogenous sequential chemiluminescent digoxin assay based on luminescent oxygen channeling technology (LOCI digoxin assay) with improved specificity towards digoxin. The potential interference of oleandrin and oleander extract on this relatively new digoxin assay has not previously been reported. The study described here reports findings of bidirectional (positive/negative) interference of oleandrin and oleander extract on the newer LOCI-based digoxin assay.

\section{MATERIALS AND METHODS}

Oleander plant was obtained from a local nursery. Oleandrin was purchased from Sigma-Aldrich Chemical Company (St. Louis, MO). Digoxin concentrations were measured using the Dimension Vista 1500 analyzer and LOCI digoxin assay, both obtained from Siemens Diagnostics (Deerfield, IL).

The LOCI digoxin assay utilizes a specific mouse monoclonal antibody against digoxin and requires no sample pretreatment prior to assessment. The analytical measurement range of this assay is from 0.06 to $5.0 \mathrm{ng} / \mathrm{ml}$ of serum digoxin concentration. This assay has excellent precision. Over a 2-month period, the between-run coefficient of variation (CV) for the low control was $1.47 \%$ (mean: $0.84 \mathrm{ng} / \mathrm{ml}$, SD: $0.012 \mathrm{ng} / \mathrm{ml}, n=32$ ) and between-run CV for the high control was $1.24 \%$ (mean: $3.22 \mathrm{ng} / \mathrm{ml}$, SD: $0.40 \mathrm{ng} / \mathrm{ml}, n=32$ ).

Aliquots of digoxin-free serum pools were supplemented with a range of concentrations of either oleandrin $(50-5 \mu \mathrm{g} / \mathrm{ml})$, or oleander extract $(0.1-10 \mu \mathrm{l} / \mathrm{ml})$. Stock solutions of pure oleandrin in ethyl alcohol $(1 \mathrm{mg} / \mathrm{ml})$ were prepared, followed by dilution with ethanol to produce two working solutions of oleandrin with final concentrations of 0.1 and $0.01 \mathrm{mg} / \mathrm{ml}$. An ethyl alcohol extract of oleander leaf was prepared by mixing $5 \mathrm{~g}$ of dry weight leaf with $50 \mathrm{ml}$ of absolute ethyl alcohol followed by mixing in a blender; this stock solution was diluted 1:10 with ethanol to prepare the working standards. Oleandrin or oleander extract working solutions were then added to a dry test tube and the ethyl alcohol evaporated at room temperature under a gentle stream of nitrogen to remove any possible ethyl alcohol interference with the digoxin immunoassay. The dry residue was reconstituted with either an aliquot of drug-free serum or serum digoxin pools. Apparent digoxin levels were measured using the LOCI digoxin assay. Each measurement was performed in triplicate and values were expressed as the mean and one standard deviation.

Three different digoxin serum pools (digoxin pool 1, 2, and 3) were prepared by combining de-identified serum specimens from patients receiving digoxin, which were submitted for therapeutic drug monitoring. The specimens were used after performing measurements and reporting all results to the ordering clinicians, and after holding specimens for one week as required by our laboratory protocol. The study was performed using left-over discarded specimens according to guidelines of University of Texas-Houston Institutional review Board. Aliquots of digoxin pool 1 and 2 were supplemented with various amounts of pure oleandrin or oleander extract, with measurement of digoxin concentrations before and after supplementation.

In order to investigate whether oleandrin or components of oleander extract interfere with the LOCI digoxin assay in vivo, BALB/c mice (Jackson Laboratories, Bar Harbor, Maine) were orally gavaged with $200 \mu 1$ of either $20 \mu \mathrm{g}$ of pure oleandrin (dissolved in saline containing $10 \%$ ethyl alcohol) or oleander extract diluted 1:10 with normal saline (reducing the ethyl alcohol concentration to $10 \%$ by volume). The vehicle control contained no oleander but was normal saline containing $10 \%$ alcohol. Blood was drawn 1 and $2 \mathrm{~h}$ after gavage and apparent digoxin concentrations were measured using the LOCI digoxin assay. No duplicate measurements were possible due to limited specimen volume.

Because digoxin-like factors of oleander are strongly protein bound (9), the possibility of overcoming interference of oleander in the LOCI digoxin assay by measuring free digoxin in the protein-free ultrafiltrate were studied. Aliquots of a third digoxin pool were further supplemented with working solutions of oleander extract and then both total and free digoxin concentrations were measured. Protein-free ultrafiltrate was prepared by centrifuging each specimen using the Centrifree Micropartion System filter (Amicon, Danvers, MA) for $30 \mathrm{~min}$ at $1500 \times g$.

Statistical analyses were done using the two-tailed Student's $t$-test. A statistically significant difference was considered at $95 \%$ confidence interval or higher $(P<0.05)$.

\section{RESULTS}

Digoxin-free serum pools supplemented with various amounts of oleandrin or oleander extract had apparent digoxin concentrations, indicating cross-reactivity of oleandrin with the antibody for the LOCI digoxin assay. The apparent digoxin concentrations increased with increasing concentrations of oleandrin or oleander extract (Table 1).

Mice fed with vehicle control had no apparent digoxin level at either 1 or $2 \mathrm{~h}$ after administration. However, when mice were fed with oleandrin or oleander extract, significant apparent digoxin concentrations were observed 1 and $2 \mathrm{~h}$ after feeding, indicating that interferences observed with in vitro experiments are also present in 
TABLE 1. Apparent Digoxin Concentrations After Supplementing Aliquots of Drug-Free Serum with Oleandrin or Oleander Extract

\begin{tabular}{|c|c|}
\hline Specimen & $\begin{array}{c}\text { Apparent digoxin }(\mathrm{ng} / \mathrm{ml}), \\
\text { mean }(\mathrm{SD}), n=3 \\
\text { LOCI digoxin assay }\end{array}$ \\
\hline Drug-free serum & None detected \\
\hline$+50 \mathrm{ng} / \mathrm{ml}$ oleandrin & $0.11(0.01)$ \\
\hline$+100 \mathrm{ng} / \mathrm{ml}$ oleandrin & $0.15(0.03)$ \\
\hline$+250 \mathrm{ng} / \mathrm{ml}$ oleandrin & $0.19(0.01)$ \\
\hline $500 \mathrm{ng} / \mathrm{ml}$ oleandrin & $0.46(0.02)$ \\
\hline$+1 \mu \mathrm{g} / \mathrm{ml}$ oleandrin & $0.62(0.01)$ \\
\hline$+5 \mu \mathrm{g} / \mathrm{ml}$ oleandrin & $1.69(0.01)$ \\
\hline$+0.1 \mu 1 / \mathrm{ml}$ oleander extract ${ }^{\mathrm{a}}$ & $0.57(0.02)$ \\
\hline$+0.5 \mu \mathrm{l} / \mathrm{ml}$ oleander extract ${ }^{\mathrm{a}}$ & $1.12(0.01)$ \\
\hline$+1.0 \mu \mathrm{l} / \mathrm{ml}$ oleander extract ${ }^{\mathrm{a}}$ & $1.86(0.02)$ \\
\hline$+2.5 \mu \mathrm{l} / \mathrm{ml}$ oleander extract ${ }^{\mathrm{a}}$ & $2.33(0.02)$ \\
\hline$+5.0 \mu \mathrm{l} / \mathrm{ml}$ oleander extract ${ }^{\mathrm{a}}$ & $2.73(0.03)$ \\
\hline$+10.0 \mu \mathrm{l} / \mathrm{ml}$ oleander extract ${ }^{\mathrm{a}}$ & $3.46(0.01)$ \\
\hline
\end{tabular}

${ }^{\mathrm{a}}$ Microliter of standard oleander extract added to $1 \mathrm{ml}$ aliquot of the serum. Standard oleander extract was diluted with ethanol to two working standards (1:10 and 1:100 dilutions) and then, appropriate microliter quantities of working oleander standards were used for supplementation.

TABLE 2. Apparent Digoxin Concentration Measured by the LOCI Digoxin Assay After Feeding Mice with Oleandrin and Oleander Extract

\begin{tabular}{lcc}
\hline & \multicolumn{2}{c}{ Apparent digoxin concentration $(\mathrm{ng} / \mathrm{ml})$} \\
\cline { 2 - 3 } Mouse no. (dosage) & 1 h after feeding & 2 h after feeding \\
\hline 1. Vehicle control & None detected & None detected \\
2. Vehicle control & 0.06 & None detected \\
3. $20 \mu$ g oleandrin & 0.9 & 0.4 \\
4. $20 \mu$ g oleandrin & 0.8 & 0.5 \\
5. $20 \mu$ g oleandrin & 0.8 & 0.4 \\
6. Oleander extract & 1.8 & 0.7 \\
7. Oleander extract & 2.2 & 1.3 \\
9. Oleander extract & 2.3 & 1.0 \\
\hline
\end{tabular}

vivo. The half-life of oleandrin is relatively short in mice (Table 2).

Rigorous characterization of immunoassay interference due to a cross-reactant should be performed in the presence of the primary analyte (12). Therefore, aliquots of digoxin pool 1 and 2 were supplemented with various amounts of oleandrin or oleander extract and measured the digoxin concentrations again in order to compare observed digoxin concentrations with digoxin concentration of the original digoxin pool. Bidirectional interference of oleandrin on the LOCI digoxin assay was observed. In the presence of smaller amounts of oleandrin (50$100 \mathrm{ng} / \mathrm{ml}$ ), observed digoxin values were lower compared to the digoxin value of the original pool, indicating negative interference of oleandrin with the LOCI digoxin assay.
TABLE 3. Effect of Oleander Extract on Serum Digoxin Values as Measured by LOCI Digoxin Assay

\begin{tabular}{|c|c|c|}
\hline Specimen & $\begin{array}{c}\text { Digoxin }(\mathrm{ng} / \mathrm{ml}), \\
\text { mean }(\mathrm{SD}), n=3 \\
\text { LOCI digoxin } \\
\text { assay }\end{array}$ & $\begin{array}{c}\text { Bias } \\
\text { (negative/positive) }\end{array}$ \\
\hline Digoxin pool 1 & $0.98(0.02)$ & Not applicable \\
\hline$+50 \mathrm{ng} / \mathrm{ml}$ oleandrin & $0.95(0.01)$ & $-3.1 \%$ \\
\hline$+100 \mathrm{ng} / \mathrm{ml}$ oleandrin & $0.86(0.03)^{\mathrm{a}}$ & $-12.2 \%$ \\
\hline$+250 \mathrm{ng} / \mathrm{ml}$ oleandrin & $0.82(0.02)^{\mathrm{a}}$ & $-16.3 \%$ \\
\hline$+500 \mathrm{ng} / \mathrm{ml}$ oleandrin & $0.77(0.03)^{\mathrm{a}}$ & $-21.4 \%$ \\
\hline$+1.0 \mu \mathrm{g} / \mathrm{ml}$ oleandrin & $1.04(0.02)^{\mathrm{a}}$ & $+6.1 \%$ \\
\hline$+5.0 \mu \mathrm{g} / \mathrm{ml}$ oleandrin & $2.08(0.04)^{\mathrm{a}}$ & $+112.2 \%$ \\
\hline$+0.1 \mu \mathrm{l} / \mathrm{ml}$ oleander extract ${ }^{\mathrm{b}}$ & $0.94(0.03)$ & $-4.1 \%$ \\
\hline$+0.5 \mu \mathrm{l} / \mathrm{ml}$ oleander extract ${ }^{\mathrm{b}}$ & $1.32(0.03)^{\mathrm{a}}$ & $+34.6 \%$ \\
\hline$+1.0 \mu \mathrm{l} / \mathrm{ml}$ oleander extract ${ }^{\mathrm{b}}$ & $1.86(0.02)^{\mathrm{a}}$ & $+89.8 \%$ \\
\hline$+2.5 \mu \mathrm{l} / \mathrm{ml}$ oleander extract ${ }^{\mathrm{b}}$ & $2.81(0.05)^{\mathrm{a}}$ & $+186.7 \%$ \\
\hline$+5.0 \mu \mathrm{l} / \mathrm{ml}$ oleander extract ${ }^{\mathrm{b}}$ & $3.72(0.02)^{\mathrm{a}}$ & $+279.5 \%$ \\
\hline$+10.0 \mu 1 / \mathrm{ml}$ oleander extract ${ }^{\mathrm{b}}$ & $4.50(0.03)^{\mathrm{a}}$ & $+359.2 \%$ \\
\hline Digoxin pool 2 & $1.14(0.03)$ & Not applicable \\
\hline$+50 \mathrm{ng} / \mathrm{ml}$ oleandrin & $1.04(0.01)^{\mathrm{a}}$ & $-8.7 \%$ \\
\hline$+100 \mathrm{ng} / \mathrm{ml}$ oleandrin & $0.94(0.02)^{\mathrm{a}}$ & $-17.5 \%$ \\
\hline$+250 \mathrm{ng} / \mathrm{ml}$ oleandrin & $0.85(0.02)^{\mathrm{a}}$ & $-25.4 \%$ \\
\hline$+500 \mathrm{ng} / \mathrm{ml}$ oleandrin & $0.78(0.03)^{\mathrm{a}}$ & $-31.5 \%$ \\
\hline$+1.0 \mu \mathrm{g} / \mathrm{ml}$ oleandrin & $1.10(0.04)$ & $-3.5 \%$ \\
\hline$+5.0 \mu \mathrm{g} / \mathrm{ml}$ oleandrin & $2.12(0.03)^{\mathrm{a}}$ & $+85.9 \%$ \\
\hline$+0.1 \mu \mathrm{l} / \mathrm{ml}$ oleander extract ${ }^{\mathrm{b}}$ & $1.07(0.04)$ & $-6.1 \%$ \\
\hline$+0.5 \mu \mathrm{l} / \mathrm{ml}$ oleander extract ${ }^{\mathrm{b}}$ & $1.38(0.03)^{\mathrm{a}}$ & $+21.1 \%$ \\
\hline$+1.0 \mu \mathrm{l} / \mathrm{ml}$ oleander extract ${ }^{\mathrm{b}}$ & $1.99(0.02)^{\mathrm{a}}$ & $+74.6 \%$ \\
\hline$+2.5 \mu \mathrm{l} / \mathrm{ml}$ oleander extract ${ }^{\mathrm{b}}$ & $3.74(0.02)^{\mathrm{b}}$ & $+228.0 \%$ \\
\hline$+5.0 \mu \mathrm{l} / \mathrm{ml}$ oleander extract ${ }^{\mathrm{b}}$ & $4.29(0.03)^{\mathrm{a}}$ & $+276.3 \%$ \\
\hline$+10.0 \mu \mathrm{l} / \mathrm{ml}$ oleander extract ${ }^{b}$ & $4.81(0.02)^{\mathrm{a}}$ & $+321.9 \%$ \\
\hline
\end{tabular}

${ }^{\text {a }}$ Significantly different from the corresponding value of digoxin pool by independent $t$-test, two-tailed $(P<0.05)$.

${ }^{\mathrm{b}}$ Microliter of standard oleander extract added to $1 \mathrm{ml}$ aliquot of digoxin pool. In order to achieve this, standard oleander extract was diluted with ethanol to two working standards (1:10 and 1:100 dilutions) and then, appropriate microliter quantities of working oleander standards were used for supplementation.

However, observed digoxin concentrations were higher than the original digoxin concentrations (positive interference) in pools when aliquots were supplemented with $5 \mu \mathrm{g} / \mathrm{ml}$ or more of oleandrin. Similar results were observed with oleander extract (Table 3).

Because oleandrin is strongly protein-bound (9), the possibility of eliminating interference of oleander in the LOCI digoxin assay by monitoring free digoxin instead of total digoxin was studied. Digoxin pool 3 supplemented with low amounts of oleander extract $(0.1,0.5$, or $1 \mu 1$ oleander extract per $\mathrm{ml}$ of the pool) did not increase the free digoxin concentration significantly from the baseline free digoxin concentration of pool $3(0.83 \mathrm{ng} / \mathrm{ml})$. This finding indicates that monitoring free digoxin can eliminate this interference if a small amount of oleander extract present in the specimen. However, in the presence 


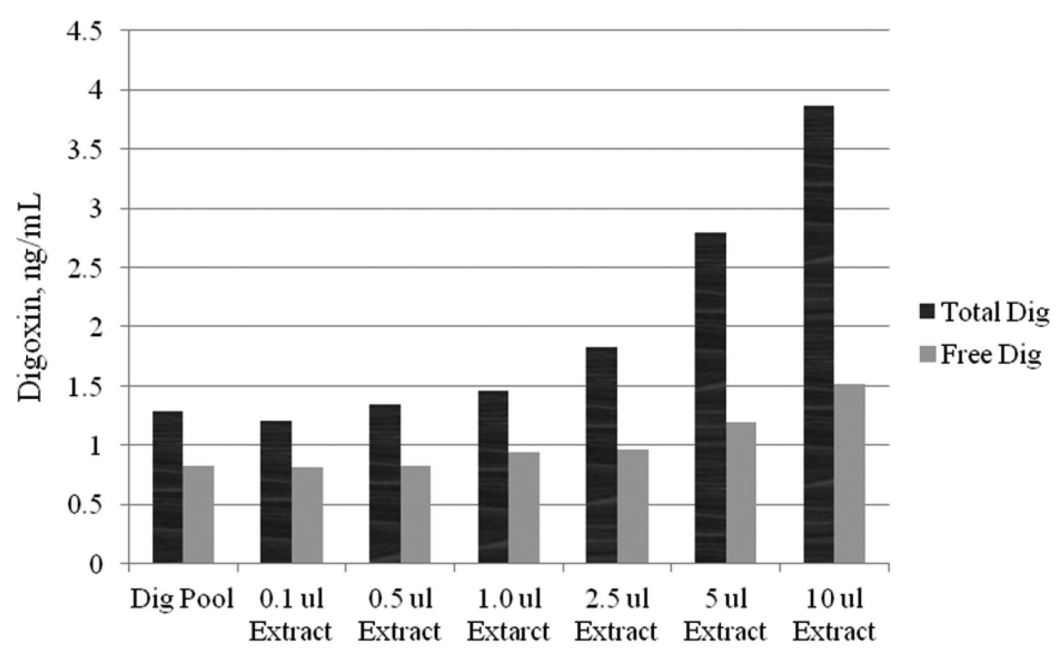

Amount of oleander extract added per $\mathrm{mL}$ of the Digoxin Pool

Fig. 1. Total and free digoxin when aliquots of a digoxin pool are further supplemented with various amounts of oleander extract. Both total (black bar) and free (gray bar) digoxin concentrations were measured by using the LOCI digoxin assay.

of higher amounts of extract, observed free digoxin concentrations increased significantly from the original free digoxin concentration of pool 3, indicating that complete elimination of this interference by monitoring free digoxin is not feasible (Fig. 1).

\section{DISCUSSION}

The popularity of herbal supplements is steadily increasing among the general population in the United States. It is estimated that roughly 20,000 herbal products are available in the United States and in one survey, approximately one of five adults reports using a herbal supplement within the past year (13). Traditionally, oleander extract was used in folk medicines for treating swelling, leprosy, skin disorders, hemorrhoids, ulcers, herpes, ringworm, as well as was used as a tonic for the heart. Several studies of oleander derivatives have yielded promising results in treating a wide variety of conditions. For example, the extract of $N$. oleander Anvirzel showed promising results in a Phase 1 clinical trial as an anticancer drug (14). Singh et al. demonstrated that oleandrin is an inhibitor of HIV infectivity (15). Oleander containing herbal supplements is readily available despite reports of severe potential toxicity from taking such herbal supplements. Therefore, it is possible that a patient taking digoxin may also take oleander containing herbal supplements. Kucukdurmaz et al. described a case of a 30-yearold healthy man who developed complete atrioventricular block after ingesting oleander preparation to relieve hemorrhoidal complaints. Fortunately, the patient recovered completely (16).
For the present study, oleandrin concentrations were selected based on those used by other investigators in reports for exploring oleandrin cross-reactivity with various digoxin assays $(6,9,10)$. Bidirectional interference of oleandrin and older extract to LOCI digoxin assay is interesting. Based on assay architecture (i.e., a wash step or its absence), the same antibody may provide a positive or negative cross-reactivity of an interfering substance in the presence of the primary analyte. While most crossreacting substances in a competitive immunoassay cause a positive interference, negative interference is observed when the ligand and the cross-reactant compete for binding sites during the reaction of the sample with the antibody reagent. If some of the poorly bound cross-reactant molecules are displaced by the immunoassay label in the following steps of the immunoassay, excess signal compared to analyte concentration is produced with falsenegative results.

Significant interference of oleandrin and oleander extract both in vitro and in vivo was observed with the relatively new LOCI digoxin assay, indicating that oleander interferes with the relatively new LOCI digoxin assay for application on Dimension analyzers. As a result, this assay is not suitable for therapeutic drug monitoring of digoxin for a patient exposed to oleander or taking any oleander containing herbal supplement. However, if a patient is exposed to oleander, but not taking digoxin, observation of apparent digoxin levels in the serum may be useful for indirect diagnosis of oleander poisoning. For the past 20 years, FPIA marketed by the Abbott laboratories was used for indirect indiction of oleander poisoning in a suspected patient $(7,8,10)$. Longford and Boor commented that small children and domestic livestocks are 
at increased risk of oleander poisoning (17). In a recent review, Bandara et al. discussed in detail oleander toxicity including diagnosis and management, and commented that FPIA digoxin assay is suitable for indirect diagnosis of oleander poisoning in a suspected person (18). However, with discontinuation of this assay, it is a challenge to indirect diagnosis of oleander poisoning using digoxin assay. Our investigation indicates that LOCI digoxin assay on the Vista 1500 analyzer has enough cross-reactivity with oleandrin and this assay can also be used for indirect diagnosis of oleander poisoning in a suspected individual. However, for a medical legal case, direct determination of oleandrin in serum or plasma of a patient using mass spectrometric method is essential. Toe et al. described a liquid chromatography combined with tandem mass spectrometric method for determination of oleandrin in tissue and biological fluids (19).

\section{REFERENCES}

1. Shawn D, Pearn J. Oleander poisoning. Med J Aust 1979;2:267269.

2. Blum LM, Reiders F. Oleander distribution in a fatality from rectal and oral Nerium oleander extract administration. J Anal Toxicol $1987 ; 82: 121-122$

3. Saravanapavananthan N, Ganeshamoorthy J. Yellow oleander poisoning: A case study of 170 cases. Forensic Sci Int 1988;36:247-250.

4. Brewster D. Herbal poisoning: A case report of fetal yellow oleander poisoning from the Solomon Island. Ann Trop Paediatr 1986;6:289-291.

5. Langford S, Boor PJ. Oleander toxicity: An examination of human and animal toxic exposure. Toxicology 1999;109:1-13.

6. Papi L, Luciani AB, Forni D, Giusiani M. Unexpected double lethal oleander poisoning. Am J Forensic Med Pathol 2012;33:93-97.
7. Cheung K, Hinds JA, Duffy P. Detection of poisoning by plant origin cardiac glycosides with the Abbott TDx analyzer. Clin Chem 1989;35:295-297.

8. Osterloh J. Cross-reactivity of oleander glycosides. J Anal Toxicol 1988;12:53.

9. Jortani SA, Helm R, Valdes R. Inhibition of Na,K-ATPase by oleandrin and oleandrigenin and their detection by digoxin immunoassays. Clin Chem 1996;42:1654-1658.

10. Dasgupta A, Datta P. Rapid detection of oleander poisoning by using digoxin immunoassays: Comparison of five assays. Ther Drug Monit 2004;26:658-663.

11. Dasgupta A, Klein K, Risin SA, Actor JK. Rapid detection of oleander poisoning by Dimension Vista digoxin assay (Flex reagent cartridge). J Clin Lab Anal 2011;25:105-109.

12. Miller JJ, Valdes R. Methods for calculating cross-reactivity in immunoassays. J Clin Immunoassay 1992;15:97-100.

13. Bent S. Herbal medicine in the United States: Review of efficacy, safety and regulation. J Gen Intern Med 2008;23:854-859.

14. Mekhail T, Kaur H, Ganapathi R, Budd GT, et al. Phase 1 trial of Anvirzel in patients with refractory solid tumors. Invest New Drugs 2006;24:423-427.

15. Singh S, Shenoy S, Nehete PN, Yang P, et al. Nerium oleander derived cardiac glycoside oleandrin is a novel inhibitor of HIV infectivity. Fitoterapia 2013;84:32-39.

16. Kucukdurmaz Z, Karapinar H, Gul I, Yilmaz A. Complete atrioventricular block after self-ingestion of Nerium oleander for relief of hemorrhoidal complaints. Turk Kardiyol Dern Ars 2012;402:168-170.

17. Langford SD, Boor PJ. Oleander toxicity: An examination of human and animal toxic exposures. Toxicology 1996;109:1-13.

18. Bandara V, Weinstein SA, White J, Eddleston M. A review of the natural history, toxicology, diagnosis and clinical management of Nerium oleander (common oleander) and Thevetia peruviana (yellow oleander) poisoning. Toxicon 2010;56:273-281.

19. Toe ER, Fillgenzi MS, Puschner B. Determination of oleandrin in tissues and biological fluids by liquid chromatography-electrospray tandem mass spectrometry. J Agric Food Chem 2005;53:43224325. 